\title{
Alternative View of Unemployment Issue among Saudi Citizens - Automatization of Local Gas Stations as a Case Study
}

\author{
Mohammed Ahmed Al Yousif \\ Economic Research Department, Saudi Central Bank, KSA \\ P.O Box 2992, Riyadh 11169, Saudi Arabia
}

Tel: 966-11-463-3000Ｅ-mail: malyousef2@sama.gov.sa; mykfsa@gmail.com

Received: June 23, 2021 Accepted: September 10, 2021 Published: September 25, 2021

doi:10.5296/ber.v11i3.18781～URL: https://doi.org/10.5296/ber.v11i3.18781

\begin{abstract}
The primary objective of this paper is to propose an alternative solution for unemployment among Saudi youth. This paper seeks to address the problem of unemployment in Saudi Arabia from a different perspective: productivity aspect. Substantially, this paper proposes solutions for the Saudi youth unemployment problem by increasing the non-oil private sector's productivity. It evaluates the macroeconomic gains of the proposed solutions, such as the number of new jobs for Saudi citizens and additional value-added. The research's main hypothesis is that increasing the non-oil private sector's productivity would significantly reduce unemployment among Saudi citizens. There are two methodologies for evaluating the expected economic benefits of increasing productivity in local economic activities. The first methodology, which is the Saudization of local gas stations by transforming the local gas stations into self-service ones (with one cashier every 8 hours for each gas station), finds that there would be more than 28,000 new jobs with reasonable salaries (at least SAR 3000 instead of SAR 1000 for at least 5 low-skilled foreign laborers) for unemployed Saudi citizens, which are socially accepted and at no additional cost to the government. The second methodology uses Leontief's IO model to estimate the macroeconomic effects of increasing productivity in the non-oil private sector. It finds that the Saudi gross domestic product (GDP) is expected to record an additional growth rate of around 2.7 percentage points (Note 1) and to create more than 96,000 sustainable jobs for Saudi citizens within the period from 2021 to 2025.
\end{abstract}

Keywords: Production aspect, Marx's organic composition of capital, Structural change, Leontief IO, Marx's circular mode of production, Sustainable job, Future job, Diversification, 
Productivity, Small and Medium enterprises (SMEs)

JEL Classification: J01, J08, J21, J24, J28, J31, O32, O41, O47, C67

\section{Introduction}

Before the discovery of oil, the occupations available to the Saudi population were related to their geographical locations. For instance, on the eastern coast of Saudi Arabia, dominant economic activities were fishing, pearl diving, trading, and farming. Occupations of people who lived in the middle of Saudi Arabia were significantly different. Since this region is far from the sea and lacks fresh water, people were dependent on cattle rearing as a leading source of income. People in the north and south of Saudi Arabia engaged mainly in the same economic activities as of those lived in the middle region. The two Islamic holy places are located in the western region of Saudi Arabia. Thus, the main economic activities for people in this region were highly related to serving pilgrims, e.g. trading and hospitality (Al-Turaiqi, 2008). After the discovery of oil in 1938, the Saudi economic structure shifted significantly and Saudi Arabia became one of the world's major suppliers of crude oil. Accordingly, the Saudi standard of living (level of income) has increased dramatically. Nevertheless, there is a notable mismatch between productivity in the oil sector and productivity in the non-oil private sector. The oil sector is well developed while the private sector, especially retail and construction, is less developed. In addition, the Saudi non-oil private sector has relied for decades on low-skilled/low-wage foreign workers. Therefore, this sector could not offer suitable jobs for Saudi citizens with a high standard of living and education.

The issues addressed in this paper, i.e. high rate of unemployment among Saudi youth and low productivity in the Saudi non-oil private sector, are not easy to resolve. However, the paper should make a significant contribution to the existing literature by discussing the negative impact of low-level productivity in the Saudi non-oil private sector. The first section of this paper will provide the theoretical foundation, including a discussion on the issue of unemployment. The second section includes empirical works that calculate the expected economic output from increasing productivity in the Saudi non-oil private sector by using the Leontief IO model. The third section will include the conclusion, recommendations, and suggestions for future researchers.

\section{Youth Unemployment in Saudi Arabia}

The high rate of unemployment among Saudi youth is one of the most controversial topics for economists (Alrasheedy, 2017; Kaboub, Forstater, \& Kelsay, 2015). The form of unemployment among Saudi citizens is believed to be structural unemployment which temporary solutions cannot address. Structural unemployment, in this research, means a mismatch between the job opportunities and the skills and education levels of the unemployed Saudi youth. After the discovery of oil, moreover, Saudi Arabia witnessed a rapid transformation from an agriculture-based economy to an industry-based economy (El Mallakh, 2015). On the other hand, the Saudi non-oil private sector, which handles most of the government development projects, was built on two fundamentals: low-wage workers and cheap energy sources (gasoline and electricity). Since Saudi Arabia faced a shortage of local 
workers in terms of quantity and quality in the early stages of development, millions of foreign workers were employed to construct the new government development projects, such as roads, hospitals, and schools, as well as other infrastructure projects (Ramady, 2010). One result of this rapid transformation was the creation of an imbalance between real income and non-oil productivity. This section will discuss the issue of unemployment by studying the tradeoff between capital/workers and wage/productivity.

From the literature, it is important to investigate the relationship between growth and structure change. The area of interest is to investigate the kind of unemployment resulting from the dynamic change in the structure of production. There is a fundamental difference between economic growth and economic structural change (Doyle, 1997). Economic growth is the amount of expansion in the domestic production of goods and services during the year, while economic structural change is the change in the composition of economic activities (Feldman, McClain, \& Palmer, 1987; Kuznets, 1973). Economic structural change is an institutional change in local economic activities, such as moving from labor-intensive economic activities to capital-intensive (industrial) economic activities. Kuznets (1973) found a strong relationship between economic structural change (such as increasing labor productivity) and economic growth. In that sense, increasing labor productivity means boosting economic growth due to increasing the standard of living for the employees (Kuznets \& Murphy, 1966). However, Marx's organic composition of capital, which is an important theoretical framework for studying unemployment, concludes that the relationship between economic structural change and economic growth is not necessarily positive.

By illustrating the circular mode of production, moreover, Marx studied the change in the organic composition of capital (c/v), where ' $\mathrm{C}$ ' referes to capital \& machines and ' $\mathrm{V}$ ' referes to laborers. For instance, an artificial economy has only two departments: department I produces machines and equipment $(\mathrm{c} 1+\mathrm{v} 1+\mathrm{s} 1)$, where $s$ refers to surplus value, and department II produces intermediate raw materials, food, and services (c2 + v2 + s2). Under the fixed organic composition of capital, promoting existing production activities shall increase demand on both departments I \& II. There is an expected expansion in department I and department II due to the permanent new demand for machines and equipment as well as goods and services from new employees in department I (Fan-Hung, 1939). Thus, expansion in the entire production system is going to take place gradually/dynamically, which means employing more workers and capital. The aggregate demand and the rate of employment would be stable as long as the level of technology (new innovation) was hold steady and workers' wages matched with their productivity, due to the low level of unemployment. However, if the behavior of the producers changed to adopt more machines and employ fewer laborers, the level of unemployment would increase. Increasing the level of unemployment should reduce the average workers' wages to a level that is lower than their productivity. Therefore, the new unemployed laborers are resulting from replacing laborers with machines in sector I and are shrinking in sector II due to a continuous decline in the local demand and purchasing power. Overall, the economy would experience shrinkage in domestic demand and a higher rate of unemployment coming from these two sectors (I and II).

To avoid adverse shocks of a structural change caused by having a dominant sector of 
production such as oil sector, on the other hand, the economic system must be highly flexible (diversified) in terms of the existence of many well-established sectors of production (Forstater, 1999b). A flexible economy involves an economic framework that requires less time to absorb any shock, whether it be endogenous or exogenous, due to a high rate of diversification. The level of dependency between production sectors should not be very high. In the case of a high level of dependence, any crisis in one segment of production would affect the entire system of production. A flexible economy is highly dynamic in terms of restructuring the production system in a very short time. Therefore, if there were a crunch in one sector of production, displaced workers would be employed by other sectors of production for two primary reasons: (1) the new industry would continue to exist, and (2) one sector would not have a significant negative effect on the economy as a whole. Accordingly, laid-off employees should have new jobs, whether in a new sector of production or in the existing sector of production, in a very short time. The new demand from the new sector would enhance the existing sector enough to expand its production. Therefore, a flexible economy is capable of maintaining a lower unemployment rate. However, in an economy with only one main sector of production, any slowdown in demand for labor would affect the entire economy. The diversification of economic activities is an essential source of stability and resilience. A flexible economy must be capable of adopting changes in technology, the supply of natural resources, consumer demand, labor demand, and other economic factors (Forstater, 1999b). Overall, one of the main initiatives of Saudi Vision 2030 is to drive the Saudi economy toward more diversification as a promising solution for many economic issues, such as unemployment.

\section{Discussion}

\subsection{Marx's Circular Mode of Production and Leontief's Input-Output (IO) Model}

This paper seeks to build a bridge between Marx's circular mode of production and Leontief's input-output model (IO). In the form of Marx's circular mode of production, which is the theoretical foundation for this research as discussed in the literature section, and the Leontief's IO model, that is the empirical instrument. Furthermore, this paper proposes a policy plan for driving the Saudi economy toward diversification, sustainability, and stability of economy by increasing productivity in the non-oil private sector. It is not expected to increase productivity in the non-oil private sector to the level of the primary export sector (i.e. oil sector) because there must be some job opportunities for low-skilled and low-educated citizens. The empirical work seeks to evaluate the expected output resulting from increased productivity in the non-oil private sector.

There are two major sectors of production for Saudi Arabia, which are primary sector-the oil sector (department I) and the non-oil sector (department II).

Department I: (primary sector [oil sector]):

$$
\mathrm{c} 1+\mathrm{v} 1+\mathrm{s} 1=\mathrm{V} 1
$$

Department II: (the non-oil sector [government and private sectors]): 


$$
\mathrm{c} 2+\mathrm{v} 2+\mathrm{s} 2=\mathrm{V} 2
$$

Before discussing the methodology of this paper, there should be a brief explanation of Leontief's IO (LFIO) model. In the $19^{\text {th }}$ century, Marx developed the two-department model, comprising two departments of production. Marx's two-department model may have somewhat influenced LFIO model. Through his input-output model, Leontief seeks to calculate the coefficient tradeoff between all sectors of production in a closed economy (excluding the external sector). The next step of his model is to calculate the amount of transactions in terms of value between the internal and external sectors. In addition, Leontief wrote two papers: "Die Wirtschaft als Kreislauf" ("The Economy as a Circular Flow") (Leontief, 1928) and "Quantitative Input-Output Relations in the Economic System of the United States" (Leontief, 1936). These two papers were considered the new quantitative microeconomic method for tracing economic activities (Murray, 2010; Rodrigues et al., 2016).

Furthermore, Leontief's IO model is capable of describing changes in the economic system resulting from any exogenous shock in terms of the fact that any expansion in one sector of production should affect the other sector of production. For instance, a specific expansion in the non-oil private sector of production should carry over to both local and primary departments due to the new demand for goods and services from the new employees in the non-oil private sector. Expansion in the entire production system will take place gradually, which is an expected result of employing more workers and purchasing more capital. Leontief's model tracks the flow of goods and services throughout the entire economy under study. For any economic system, there is an existing flow of goods and services between different sectors of economic activities. The input-output model was designed to track these goods and services that are exchangeable between different sectors of production (Miller, 1998). For example, a certain economy has three sectors of production: A, B, and C. The total output of sector (A) is supposed to be consumed by the sector itself and by the other sectors of production, such as (B) and (C). In addition, the total production of goods and services from the other sectors (B and $\mathrm{C}$ ) should be consumed among themselves and some of these goods and services might be input for the sector of production (A). In the IO table, there are columns and rows. The columns contain the flows of goods and services from one sector of production to others (see Table A). On the other hand, the rows of the table include information about the distribution of input to each sector of production. For an internal system, the total output of all sectors of production must equal the total input. In addition, some input and raw materials are imported from outside the domestic system (outside the country). Some output would also be consumed by entities outside the system of production or even exported outside the country. These transaction flows between the domestic system of production and the entities outside the system of production should be recorded in the Final Use table (see Table B). In short, the second wave of production shall be consumed by the final users, which are users outside the production scheme including government spending, household consumption, investors' investments, and exports. These types of information could be obtained from the input-output table as well as detailed information about the flows of goods and services between internal sectors of production and the final demand sector 
through supply and demand tables. The supply table includes the total amount of output of each sector of production, while the demand table contains information about the distribution of these goods and services to internal production entities and the final demand users. There are two primary methods for changing the structure of production: changing the level of technology and the final demand. For the sake of simplicity, the level of technology (A) for different sectors of production is assumed to be unchangeable. As a result, the coefficients between different sectors of production are fixed in the medium term (three to five years). However, the final demand might change (increase or decrease) due to some exogenous variables. For instance, if the government decided to encourage local investors by reducing the level of taxation, investors would have more money for investment. This increase in the level of investment would enhance expansion throughout the entire sectors of production. A well-established I-O table should help policymakers estimate the amount of expansion throughout the entire economic system; it will reveal the relationship between the rate of taxation and the level of production as a result of the movement in the level of investment. Thus, Leontief's methodology could be used to evaluate any government plan or policy in the short and medium terms (between two and three years) (Miller \& Blair, 2009).

The non-oil private sector usually responds to change in the final demand sector. Leontief's model handles the demand from the final users in the aggregate level because the final demand sector is determined by some exogenous factors. Thus, the economy has $\mathrm{n}+1$ $\operatorname{sectors}(n$ here indicates the number of production sectors) and the aggregate final demand sector. Each sector of production produces goods and services. Part of this production would be consumed by the production sectors, while the final demand sector would consume the rest of the output. Therefore, the total goods and services, which a particular production sector creates, shall be consumed by sectors of production (n) and the final demand sector. In short, the input-output table displays the flow of goods and services among all economic production sectors and final demand users (Al Yousif \& Al Backer, 2017; Al Yousif, 2018).

$$
\begin{gathered}
\Sigma \mathrm{X}_{\mathrm{i}}=\mathrm{a}_{11} \mathrm{X}_{1}+\mathrm{a}_{12} \mathrm{X}_{2}+\ldots+\mathrm{a}_{\mathrm{ij}} \mathrm{X}_{\mathrm{j}}+\mathrm{FD}_{\mathrm{i}} \\
\mathrm{X}=\mathrm{AX}+\mathrm{FD} \\
(\mathrm{I}-\mathrm{A}) \mathrm{X}=\mathrm{FD} \\
\mathrm{X}=(\mathrm{I}-\mathrm{A})^{-1} \mathrm{FD}
\end{gathered}
$$

From equation (3), $\Sigma X_{i}$ is the total output for all sectors of production (i). The total output of each sector of production is divided into two parts. A portion of $\mathrm{X}_{\mathrm{i}}$ 's output is used as input to the $X_{i}$ sectors $\left(x_{i j}=a_{i j} X_{i}\right)$. ' $a_{i j}$ ' is the ratio of output that each sector of production consumes, which could be simplified in this equation $\left(\mathrm{a}_{\mathrm{ij}}=\mathrm{x}_{\mathrm{ij}} / \mathrm{X}_{\mathrm{i}}\right)$. In Table $\mathrm{A}$, the columns contain information about the total output of each sector of production, while the rows include the total input for all sectors of production. The final use section $\left(\mathrm{FD}_{\mathrm{i}}\right)$, which includes the government, households, investors, and exports, consumes the rest of the produced output as outside entities from the production scheme.

In equation (4), $\mathrm{X}$ is a matrix-vector in which notation $\mathrm{X}$ is an i-by-1 matrix containing the total output of each sector of production. This total output is distributed to itself and other 
sectors of production, while the rest of this output flows to the final demand users, such as the government and households. On the right side of equation (4) is the ' $A$ ' matrix, which is a square matrix (i-by-j). The ' $A$ ' matrix contains the percentage of distribution of output to each sector of production. Therefore, the ' $A$ ' matrix includes $\mathrm{a}_{\mathrm{ij}}=\mathrm{X}_{\mathrm{ij}} / \mathrm{X}_{\mathrm{i}}$ values. The final demand users $\left(\mathrm{FD}_{\mathrm{i}}\right)$ would consume the rest of the output for all production sectors.

From equation (4), there is no existing eigenvalue between the sectors of production and the final user sector. Equation (5) adds all the X's on the left side, which could be considered a first step toward building the eigenvalue. In short, the left-hand side represents the domestic sector, while the right-hand side represents the distribution of X's to the final users. Earlier in this paper, the level of technology was assumed to be constant for short and medium times. Accordingly, the change in the production system must come from the final demand. Equation (6), which is derived from equation (5), shows a direct relationship between these main sectors through an inverse matrix $(\mathrm{I}-\mathrm{A})^{-1}$. Hence, $(\mathrm{I}-\mathrm{A})^{-1}$ is Leontief's inverse matrix, which displays the kind of relationship between the production sector and the final demand sector. Having Leontief's inverse matrix is the final step needed to calculate the relationship between $\Delta \mathrm{FD}_{\mathrm{i}}$ and $\Delta \mathrm{X}_{\mathrm{i}}$ (Albqami, 2004; Rose \& Miernyk, 1989).

From the Saudi national account table, we can calculate the input-output table for Saudi Arabia. The recent input-output table (2017) was published in 2018 (Note 2) with 17 economic activities (see Table A). It shows the Saudi input and output for 2017. This table includes 17 sectors of production: agriculture and forestry (ACT1); fishing (ACT2); crude petroleum and natural gas extraction (ACT3); other mining (ACT4); petroleum refining (ACT5); other manufacturing (ACT6); electricity, gas, and water (ACT7); construction (ACT8); wholesale and retail trade (ACT9); restaurants and hotels (ACT 10); transport, storage, and communication (ACT11); finance, insurance, and real estate (ACT12); business services and ownership of dwellings (imputed rent) (ACT13); public administration and defense and compulsory social security (ACT14); education (ACT15); health and social work (ACT16); and other community, social, and personal service activities (ACT17). Table A (see Appendix A) places these economic activities (domestic production sectors) into columns and rows (17 columns and rows). The flows of goods and services in columns ACT1 to ACT17 represent the amount of input to specific sectors of production in terms of value from other production sectors. The rows of the IO table show the flows of input to the domestic production sectors.

Furthermore, the total value of each row of a particular production sector represents the total amount of output in terms of the value of this sector of production. Table A contains 17 by 17 economic sectors, and the system of the input-output table should indicate a balance between the amount of output in the rows and the input in the columns. According to these interactions among the internal sectors, any increase in demand from one internal sector would create a change in the entire production system as the balance between the total input and output should be maintained. For example, if the manufacturing sector increased the demand in the construction sector, the construction sector would have to expand to meet the new demand from the manufacturing sector. This expansion in the construction sector would increase demand for the other sectors of production as well. Such increase in the demand by the 
manufacturing sector would extend with different amounts to all production sectors. As a result, the entire system of production would expand. The LFIO evaluates trade-offs among different sectors of production in riyals as the amount of output from sector ACT1 goes to sector ACT2 and vice versa.

The first part of the Leontief input-output table explains the domestic production system and records the flows of interaction between different sectors of production. Meanwhile, the second part of the table represents the final demand sector. Table B contains the amount of demand from the final users sector to the domestic production sector. The final users are the main drivers for the domestic production sector. They are determined by some exogenous factors, such as the increase in government oil revenue or increase in the global demand for domestic goods and services. This increase in demand for domestic production from the final users would enhance development in the domestic production system and result in further expansion in the production scheme. The final demand table includes the total demand from economic entities outside the production sector. This table presents the total amount of demand by each entity in the domestic production sector. However, in our case, the Final Use table (Table B) includes the final consumption expenditure by households (FUSE1), the final consumption expenditure by the government (FUSE2), the total final consumption expenditure (FUSE3), gross fixed capital formation (FUSE4), changes in inventories and errors and omissions (FUSE5), exports of oil (FUSE6), exports of non-oil goods (FUSE7), exports of services (FUSE8), total exports (FUSE9), and total final use (FUSE10) (see Appendix B). Finally, the Value Added table (Table C) explains the GDP. It presents the total value resulting from the domestic production sector for a year. This table also includes the compensation of employees, other taxes less subsidies on production, and the operating surplus (see Appendix C).

As mentioned previously, the current Saudi non-oil private sector seems to have low level of productivity. Likewise, the Saudi private sector has no incentive to increase its employees' productivity by investing in very expensive machines and technology as long as they have easy access to the low-wage and low-skilled laborers, especially from abroad. The other reason could be the vey low level of competition between local companies. In addition, investment of a large amount of money in new machines and high-tech equipment is required for long-term projects and a sustainable flow of projects from the government. To make the Saudi private sector more attractive to citizens, however, the level of productivity in the private sector has to increase. Increasing productivity in the private sector should guarantee to provide acceptable jobs for a long list of local specialists. Nevertheless, the large domestic corporations' structures are not easy to change, and it is very costly to make changes from up to down.

To overcome these barriers that prevent additional development in the domestic private sector's productivity, it is necessary to encourage further growth in the Saudi small and medium-sized enterprises (SMEs). Thus, the research proposal has been designed to enhance diversification and productivity by encouraging development in SMEs. SMEs also have the capability of having more pronounced division of labor that should capture all kinds of laborers with an extended range of skills and specialities. As long as the significant majority 
of unemployed Saudis have a high level of education and training from top-ranked universities, they will require particular jobs that better match their education levels.

Small and medium-sized enterprises (SMEs) are playing a vital role in the stability and sustainability of any economy. Saudi engineers and technicians, who are part of the local community, should handle the diversification in Saudi Arabia through small and medium-sized enterprises. SMEs are considered the primary source of diversification, as they are willing to take on more high-risk projects. It is healthier for the economy to distribute risky projects to SMEs, as any collapse in large corporations would have a significant effect on the economy. At this time, Saudi SMEs need more support from the government financially. Government spending should consider encouraging growth of SMEs and provide special training programs for fresh graduates. Recently, the Saudi government has moved toward enhancing development in the SMEs. SME development, in particular, should be part of the government's programs aiming to increase productivity in the domestic non-oil private sector.

Overall, there are many strategies that the government can adopt to enhance the development in the local SMEs, developing SMEs would help the government and the private sector to provide investment of around SAR 170 billion for five years (2021-2025) to increase efficiency and productivity in the non-oil private sector, the SMEs in specific. The amount of investment would fund the purchase of new machines and equipment for the non-oil private sector and the provision of training programs. The output of this sector (X) will increase as a result of an increase in its productivity. Leontief IO (2017) table for Saudi Arabia shows that an increased investment of SAR 34 billion each year for five years would expand the domestic production system by around 1 percent in 2021 and by over 2 percent for the following year. Ultimately, the total accumulated expansion of the production system will reach around 5 percent at the end of the five years (Table 1).

Table 1. Changes in the Production System Based on SAR 170 Billion Investment for 5 Years

\begin{tabular}{|l|l|l|l|l|l|}
\hline Year & 2021 & 2022 & 2023 & 2024 & 2025 \\
\hline Expansion in non-oil production sectors (Xs) & $1.09 \%$ & $2.16 \%$ & $3.17 \%$ & $4.10 \%$ & $4.92 \%$ \\
\hline
\end{tabular}

Note. Author's calculation.

Expansion in the domestic production system would likely flow to the GDP. Therefore, expansion in the GDP is estimated to be around 0.6 percent in 2021 and continue to grow to reach around 2.7 percent by the end of 2025 (see Table 2). This expected increase in the GDP is driven primarily by the expected increases in capital surplus and the number of employees, as shown in Table 2.

Table 2. Changes in Value Added (GDP) Based on SAR 170 Billion Investment for 5 Years

\begin{tabular}{|l|l|l|l|l|l|}
\hline Year & 2021 & 2022 & 2023 & 2024 & 2025 \\
\hline Estimated expansion in the GDP & $0.6 \%$ & $1.2 \%$ & $1.7 \%$ & $2.3 \%$ & $2.7 \%$ \\
\hline
\end{tabular}

Note. Author's calculation 
Table 3 calculates the number of new jobs that would be generated as a result of increased investment in the domestic economy of SAR 170 billion for five years (2021-2025). In the first year of investment (2021), the number of new jobs is estimated at 22,752. The number of new jobs is expected to increase dramatically, and it is estimated to be around 178,100 by the end of 2025, as shown in Table 3.

Table 3. Number of New Jobs in the Non-Oil Sector Based on SAR 170 Billion Investment for 5 Years

\begin{tabular}{|l|l|l|l|l|l|l|}
\hline Year & 2021 & 2022 & 2023 & 2024 & 2025 & Total number of jobs (2001-2004) \\
\hline New jobs generated & 22,752 & 28,358 & 34,896 & 43,548 & 48,546 & 178,100 \\
\hline
\end{tabular}

Note. Author estimations

\subsection{Automization of Local Gas Stations}

There are three features for sustainable occupations, which are aimed to be identified in this paper. The future path of sustainable occupations must be clear, with a close relationship between productivity and wages, and it should be flexible enough to adopt any future structural changes. Before the problem of high unemployment rate among Saudi youth becomes so complicated, it is necessary to propose a solution for it. In other words, some precautionary solutions that would prevent the economy from experiencing this issue in the future with worse outcomes are necessary. There is a need to create a strategic plan for increasing development and productivity in the non-oil private sector to a level that is close to the primary export sector's level. This step aims to transform the Saudi economy into a more resilient economy.

For instance, one solution to the high rate of unemployment among Saudi youth is the Saudization of the modern local gas stations. The number of gas stations in the Kingdom of Saudi Arabia was estimated at 8,000 (Note 3). The average number of low-skilled and low-income workers for each gas station was estimated to be no less than 12 workers (four workers for every eight hours). Therefore, the number of foreign employees working at local gas stations is, on average, around 100,000 (Author's calculation). Instead of having four or more workers filling cars with gasoline on each shift, these local gas stations could use high-tech pumps and employ one cashier to manage the entire gas station. Employees in these new automated gas stations would be eligible for higher payment, which could be equivalent to the amount of payment given to four or more low-skilled workers. In addition, this occupation has a higher learning curve, such as handling the newest technology and learning managerial skills. Generally, this example supports this paper's hypothesis, which states that increasing local productivity would create more jobs for Saudi citizens. On the other hand, the cost of improving the existing old-style gas stations might be very high that the owners of these gas stations would refuse to carry out such improvement. However, this study does not suggest an immediate change of all gas stations in the Kingdom. In addition, the government should provide some motivational packages and some financial support, such as loans with free interest, to increase the speed of the transformation into modern high-tech gas 
stations.

Table 4 indicates that there are some great job opportunities for Saudi citizens at modern local gas stations for several reasons. Working at new automated gas stations requires a certain level of education and skills because it requires using computers and complicated software. In addition, this occupation requires accounting, management, and operation skills. Therefore, the volume of experience and training expected to be given to modern gas station employees is very high. Consequently, the future path of this occupation would be promising. Moreover, working in automated gas stations would be very socially accepted due to the high income and productivity, which are important features for sustainable occupations as proposed by this paper.

Table 4. Main Features of Occupation in Automated Gas Stations vs. Traditional Gas Stations

\begin{tabular}{|l|l|l|}
\hline & Traditional gas station & Automated gas station \\
\hline Education \& Skills & Low & High \\
\hline Wages & Low & High \\
\hline Training & Low & High \\
\hline Future Path & Low & High \\
\hline Technicality & Low & High \\
\hline Social Acceptance & Low & High \\
\hline
\end{tabular}

Note. Author's view.

The next step in this section is to estimate the number of new jobs for Saudi citizens at local self-service gas stations. The cost of automated gas stations will be high, but the expected benefits of this structural change are significant. Employing more Saudi citizens, who would make a considerable contribution to the local economic demand, would increase domestic demand and growth. This paper proposes three scenarios (Tables 5, 6, and 7). Each scenario consists of a different number of gas stations $(7,000 ; 8,000$; and 9,000) with three categories: small, medium, and large (30\%, 40\%, and 30\%).

Table 5. First Scenario of 7,000 Local Gas Stations

\begin{tabular}{|c|c|c|c|c|c|}
\hline $\begin{array}{l}\text { Number of gas } \\
\text { stations }\end{array}$ & $\begin{array}{ll}\text { Small } & \text { size } \\
(30 \%) & \\
(2,100 & \text { gas } \\
\text { stations }) & \end{array}$ & $\begin{array}{ll}\text { Medium } & \text { size } \\
(40 \%) & \\
(2,800 & \text { gas } \\
\text { stations }) & \end{array}$ & $\begin{array}{ll}\text { Large } & \text { size } \\
(30 \%) & \\
(2,100 & \text { gas } \\
\text { stations }) & \end{array}$ & $\begin{array}{l}\text { Total number } \\
\text { of workers in } \\
\text { traditional gas } \\
\text { stations }\end{array}$ & $\begin{array}{l}\text { Expected number of } \\
\text { Saudis in modern gas } \\
\text { stations (with high } \\
\text { technology and } \\
\text { capital) }\end{array}$ \\
\hline $\begin{array}{l}\text { Total number of } \\
\text { gas stations is } \\
\text { estimated at } \\
\text { around } 7,000\end{array}$ & $\begin{array}{l}3 \text { workers on } \\
\text { each shift: } 3 \\
\text { shifts }= \\
9 \text { workers/gas } \\
\text { station } \\
\text { 'Total } \\
\text { Workers' } \\
(18,900)\end{array}$ & $\begin{array}{l}6 \text { workers on } \\
\text { each shift: } 3 \\
\text { shifts }= \\
18 \\
\text { workers/gas } \\
\text { station } \\
\text { 'Total } \\
\text { Workers' } \\
(50,400)\end{array}$ & $\begin{array}{l}9 \text { workers on } \\
\text { each shift: } 3 \\
\text { shifts }= \\
27 \\
\text { workers/gas } \\
\text { station } \\
\text { 'Total } \\
\text { Workers' } \\
(56,700)\end{array}$ & $\begin{array}{l}(126,000) \\
\text { workers }\end{array}$ & $\begin{array}{l}20,000 \\
\text { jobs for Saudi } \\
\text { citizens; } \\
3 \text { workers for each } \\
\text { gas station }\end{array}$ \\
\hline
\end{tabular}

Note. Author's calculation. 
Table 6. Second Scenario of 8,000 Local Gas Stations

\begin{tabular}{|c|c|c|c|c|c|}
\hline $\begin{array}{l}\text { Number of gas } \\
\text { stations }\end{array}$ & $\begin{array}{ll}\text { Small } & \text { size } \\
(30 \%) & \\
(2,400 & \text { gas } \\
\text { stations }) & \end{array}$ & $\begin{array}{ll}\text { Medium } & \text { size } \\
(40 \%) & \\
(3,200 & \text { gas } \\
\text { stations }) & \end{array}$ & $\begin{array}{ll}\text { Large } & \text { size } \\
(30 \%) & \\
(2,400 & \text { gas } \\
\text { stations }) & \end{array}$ & $\begin{array}{l}\text { Total number } \\
\text { of workers in } \\
\text { traditional gas } \\
\text { stations }\end{array}$ & $\begin{array}{l}\text { Expected number of } \\
\text { Saudis in modern gas } \\
\text { stations (with high } \\
\text { technology and } \\
\text { capital) }\end{array}$ \\
\hline $\begin{array}{l}\text { Total number of } \\
\text { gas stations is } \\
\text { estimated at } \\
\text { around } 8,000\end{array}$ & $\begin{array}{l}3 \text { workers on } \\
\text { each shift: } 3 \\
\text { shifts = } \\
9 \text { workers/gas } \\
\text { station } \\
\text { 'Total } \\
\text { Workers' } \\
(21,600)\end{array}$ & $\begin{array}{l}6 \text { workers on } \\
\text { each shift: } 3 \\
\text { shifts }= \\
18 \\
\text { workers/gas } \\
\text { station } \\
\text { 'Total } \\
\text { Workers' } \\
(57,600)\end{array}$ & $\begin{array}{l}9 \text { workers on } \\
\text { each shift: } 3 \\
\text { shifts }= \\
27 \\
\text { workers/gas } \\
\text { station } \\
\text { 'Total } \\
\text { Workers' } \\
(64,800)\end{array}$ & $\begin{array}{l}144,000 \\
\text { workers }\end{array}$ & $\begin{array}{l}24,000 \\
\text { jobs for Saudi } \\
\text { citizens; } \\
3 \text { workers for each } \\
\text { gas station }\end{array}$ \\
\hline
\end{tabular}

Note. Author's calculation.

Table 7. Third Scenario of 9,000 Local Gas Stations

\begin{tabular}{|c|c|c|c|c|c|}
\hline $\begin{array}{l}\text { Number of gas } \\
\text { stations }\end{array}$ & $\begin{array}{ll}\text { Small } & \text { size } \\
(30 \%) & \\
(2,700 & \text { gas } \\
\text { stations }) & \end{array}$ & $\begin{array}{ll}\text { Medium } & \text { size } \\
(40 \%) & \\
(3,600 & \text { gas } \\
\text { stations }) & \end{array}$ & $\begin{array}{ll}\text { Large } & \text { size } \\
(30 \%) & \\
(2,700 & \text { gas } \\
\text { stations }) & \end{array}$ & $\begin{array}{l}\text { Total number } \\
\text { of workers in } \\
\text { traditional gas } \\
\text { stations }\end{array}$ & $\begin{array}{l}\text { Expected number of } \\
\text { Saudis in modern gas } \\
\text { stations (with high } \\
\text { technology and } \\
\text { capital) }\end{array}$ \\
\hline $\begin{array}{l}\text { Total number of } \\
\text { gas stations is } \\
\text { estimated at } \\
\text { around } 9,000\end{array}$ & $\begin{array}{l}3 \text { workers on } \\
\text { each shift: } 3 \\
\text { shifts }= \\
9 \text { workers/gas } \\
\text { station } \\
\text { 'Total } \\
\text { Workers' } \\
(24,300)\end{array}$ & $\begin{array}{l}6 \text { workers on } \\
\text { each shift: } 3 \\
\text { shifts }= \\
18 \\
\text { workers/gas } \\
\text { station } \\
\text { 'Total } \\
\text { Workers' } \\
(64,800) \\
\end{array}$ & $\begin{array}{l}9 \text { workers on } \\
\text { each shift: } 3 \\
\text { shifts }= \\
27 \\
\text { workers/gas } \\
\text { station } \\
\text { 'Total } \\
\text { Workers' } \\
(72,900)\end{array}$ & $\begin{array}{l}162,000 \\
\text { workers }\end{array}$ & $\begin{array}{l}27,000 \\
\text { jobs for Saudi } \\
\text { citizens; } \\
3 \text { workers for each } \\
\text { gas station }\end{array}$ \\
\hline
\end{tabular}

Note. Author's calculation.

From these three scenarios, it is clear that the number of new sustainable jobs for Saudi citizens will be around 25,000 (on average). The number of new jobs at modern gas stations is expected to increase for each new gas station opening in the country. Many occupations would be suitable for Saudi job seekers after allowing the required developments to take place. For instance, many Saudi citizens work as taxi drivers through Uber and Careem. The question is: why is this job desirable to Saudi citizens? These companies use technology (applications) to provide taxi services, allow drivers to use their own personal vehicles instead of specific taxicabs, and offer very flexible working hours. Finally, the problem of unemployment among Saudis is not a problem of demand or supply. Saudization in the public sector is very high, but low in the Saudi private sector compared to its total employees. 
However, the Saudi private sector could not only observe the new generation of highly skilled Saudi young job seekers, especially in light of the significant number of low-skilled foreign laborers. It must be recalled that the economic boom led to mismatch between development plans for human resources and economic development. The large increase in oil revenues led to a staggering increase in income. On the other hand, the private non-oil sector was established to implement the government's development programs. The Saudi private sector was not established in a way that can create jobs compatible with the requirements of new Saudi job seekers, especially with regard to salaries. Therefore, this research has suggested that the private sector's level of productivity has to increase by mechanizing the system of production.

\section{Conclusion}

The main purpose of this paper is to propose a framework for creating sustainable jobs for Saudi citizens. Sustainable jobs must include two main conditions. The first condition is a clear and encouraging future path. The second condition is that a sustainable job should increase an employee's market value through special training programs. Moreover, the current economic system is not static; it is difficult to isolate any economy from the global economy in the $21^{\text {st }}$ century. A sustainable economy must be capable of adapting to these current changes or challenges. It must also be capable of adapting to changes in technologies and in supply of natural resources. Stability can be defined as an economy's ability to absorb the impact from inflationary pressures, sluggish growth, and stagnation with a high rate of unemployment. A resilient economy does not have a high rate of unemployment but, preferably, has the ability to maintain a low rate of unemployment during various economic conditions.

Recently, Saudi Arabia has witnessed an influx of highly educated and skilled citizens. The government and oil sectors could not employ all the Saudi citizens, while the private sector has been unable to create suitable jobs for the young generation. For this reason, this paper recommends improving productivity in the Saudi non-oil private sector by enhancing development in SMEs. After rebuilding the private sector with a high level of productivity and efficiency, the private sector can be relied on to drive the Saudi economy toward diversification and create more sustainable jobs for Saudi citizens. In short, the main contribution of this research is that it will guarantee a balance of development between both sectors of production (the non-oil private and primary). Productivity of the non-oil private sector must be the same, or at least at a similar level, as that of the primary sector. The domestic sector has improved over time, and new jobs for Saudi youth will be available. Further research papers should study the possibility of building a new non-primary export sector in the Saudi economy as a solution to promote additional stability and sustainability in the Saudi economy.

\section{Acknowledgement}

The views expressed are those of the author(s) and do not necessarily reflect the position of Saudi Central Bank (SAMA) and its policies. This Working Paper should not be reported as representing the views of SAMA. 


\section{References}

Albqami, R. (2004, September). Economic impact of tourism sector on Saudi Arabian economy. Paper presented at the International Conference on Input-Output and General Equilibrium, Brussels, Belgium.

Al-Turaiqi, A. (2008). The political system of Saudi Arabia. Riyadh: Ghainaa Publications.

Alrasheedy, A. (2017). Monetary policies for full employment and price stability in Saudi Arabia: An endogenous money approach (Doctoral dissertation). University of Missouri, Kansas City.

Al Yousif, M. A. (2018). Enhancing development in the Saudi renewable energy sector: A promising strategy for job creation and economic diversification (Doctoral dissertation). University of Missouri, Kansas City.

Doyle, E. (1997). Structural change in Ireland: The contribution of sectoral employment distribution to labour productivity convergence between Ireland and the EU: 1970-1990. Journal of Economic Studies, 24(1/2), 59-71. https://doi.org/10.1108/01443589710156880

El Mallakh, R. (2015). Saudi Arabia: Rush to development: Profile of an energy economy and investment. London: Routledge. https://doi.org/10.4324/9781315744414

Fan-Hung. (1939). Keynes and Marx on the theory of capital accumulation, money and interest. The Review of Economic Studies, 7(1), 28-41. https://doi.org/10.2307/2967594

Feldman, S. J., McClain, D., \& Palmer, K. (1987). Sources of structural change in the United States, 1963-78: An input-output perspective. The Review of Economics and Statistics, 69(3), 503-510. https://doi.org/10.2307/1925539

Forstater, M. (1999a). Functional finance and full employment: Lessons from Lerner for today. Journal of Economic Issues, 33(2), 475-482.

https://doi.org/10.1080/00213624.1999.11506180

Forstater, M. (1999b). Public employment and economic flexibility: The job opportunity approach to full employment. Annandale-on-Hudson, NY: Bard College, Jerome Levy Economics Institute.

Kaboub, F., Forstater, M., \& Kelsay, M. (2015). The cost of unemployment and the job guarantee alternative in Saudi Arabia (Policy Report No. 101). Binzagr Institute for Sustainable Prosperity.

Kuznets, S. (1973). Modern economic growth: Findings and reflections. The American Economic Review, 63(3), 247-258.

Kuznets, S., \& Murphy, J. T. (1966). Modern economic growth: Rate, structure, and spread (Vol. 2). New Haven, CT: Yale University Press.

Leontief, W. (1928). The economy as a circular flow. Structural Change and Economic Dynamics, 2(1), 181-212. https://doi.org/10.1016/0954-349X(91)90012-H 
Leontief, W. (1936). Quantitative input and output relations in the economic system of the United States. The Review of Economics and Statistics, 18(3), 105-12.

https://doi.org/10.2307/19278375.

Leontief, W. (1966). Essays in economics: Theories, theorizing, facts, and policies. Piscataway, NJ: Transaction Publishers.

Leontief, W. (1987). The ins and outs of input-output analysis. Mechanical Engineering, 109(1), 28-35. https://doi.org/10.1080/05775132.01.11470986

Miller, R. E. (1998). Regional and Interregional Input-Output Analysis. In W. Isard, I. Azis, M. Drennan, R. Miller, S. Saltzman \& E. Thorbecke (Eds.), Methods of interregional and regional analysis (pp. 41-134). Farnham, UK: Ashgate Publishing Limited.

https://doi.org/10.4324/9781315249056-3

Miller, R. E., \& Blair, P. D. (2009). Input-output analysis: Foundations and extensions. Cambridge, UK: Cambridge University Press. https://doi.org/10.1017/CBO9780511626982

Murray, M. J. (2010). An instrumental approach to full employment: With policy implication (Doctoral dissertation). University of Missouri, Kansas City.

Ramady, M. A. (2010). The Saudi Arabian economy: Policies, achievements, and challenges. Berlin: Springer Science \& Business Media. https://doi.org/10.1007/978-1-4419-5987-4

Rodrigues, J. F., Lorena, A., Costa, I., Ribeiro, P., \& Ferrão, P. (2016). An input-output model of extended producer responsibility. Journal of Industrial Ecology, 20(6), 1273-1283. https://doi.org/10.1111/jiec.12401

Rose, A., \& Miernyk, W. (1989). Input-output analysis: The first fifty years. Economic Systems Research, 1(2), 229-272. https://doi.org/10.1080/09535318900000016

\section{Notes}

Note 1. Especially during the recent period, where the growth rate of the non-oil private sector is below its potential with a negative output gap.

Note 2. The Supply and Use Table (2017) used in this paper for building the IO table was among the latest available data provided by the General Authority for Statistics.

Note 3. Because there were no official data available on the number of gas stations in the Kingdom, this paper relied on some unofficial sources and the author's observations. 
Appendix

2021, Vol. 11, No. 3

Appendix A. Saudi Arabia Input and Output for 2017 (SAR Millions)

\begin{tabular}{|c|c|c|c|c|c|c|c|c|c|c|c|c|c|c|c|c|c|c|}
\hline Sectors & Act $(1)$ & $\operatorname{Act}(2)$ & $\operatorname{Act}(3)$ & $\operatorname{Act}(4)$ & $\mathrm{ACT}(5)$ & $\mathrm{ACT}(6)$ & $\mathrm{ACT}(7)$ & $\mathrm{ACT}(8)$ & $\mathrm{ACT}(9)$ & $\begin{array}{l}\mathrm{ACT}(1 \\
0)\end{array}$ & ACT(11) & $\begin{array}{l}\mathrm{ACT}(1 \\
2)\end{array}$ & $\begin{array}{l}\mathrm{ACT}(1 \\
3)\end{array}$ & $\begin{array}{l}\mathrm{ACT}(1 \\
4)\end{array}$ & $\begin{array}{l}\mathrm{ACT}(1 \\
5)\end{array}$ & $\begin{array}{l}\mathrm{ACT}(1 \\
6)\end{array}$ & $\begin{array}{l}\mathrm{ACT}(1 \\
7)\end{array}$ & $\begin{array}{l}\text { Inter-Industry } \\
\text { Subtotal }\end{array}$ \\
\hline $\begin{array}{l}\text { Agriculture, } \\
\text { Forests }\end{array}$ & 5,876 & & 2,096 & & 3,065 & 61,057 & & 5,352 & & 4,683 & & & 2,393 & 1,052 & 1,133 & & 758 & $87,465.00$ \\
\hline Fishing & & & & & & 3,114 & & & & 225 & & & & & & & & $3,339.00$ \\
\hline $\begin{array}{l}\text { Crude } \\
\text { Petroleum and } \\
\text { Natural Gas } \\
\text { Extraction }\end{array}$ & & & 2,834 & 370 & 70,140 & 57,036 & 6,537 & 10,493 & & 289 & 6,007 & & & & 368 & 758 & 127 & $154,959.00$ \\
\hline Other Mining & & & & & & 16,188 & 1,212 & 11,089 & & & & & & & & & & $28,489.00$ \\
\hline $\begin{array}{l}\text { Petroleum } \\
\text { Refining } \\
\end{array}$ & 4,001 & 1,089 & 3,301 & 900 & 7,415 & 30,457 & 9,806 & 8,243 & 5,461 & 1,583 & 35,613 & 1,770 & 3,048 & 12,010 & 3,168 & 2,608 & 1,073 & $131,546.00$ \\
\hline $\begin{array}{l}\text { Other } \\
\text { Manufacturing }\end{array}$ & 9,299 & 2,201 & 8,778 & 2,200 & 2,826 & 67,895 & 9,981 & 148,807 & 24,771 & 4,357 & 26,028 & 2,407 & 10,679 & 22,961 & 10,966 & 14,323 & 4,222 & $372,701.00$ \\
\hline $\begin{array}{l}\text { Electricity, Gas, } \\
\text { and Water }\end{array}$ & 803 & 146 & 882 & 181 & 2,458 & 19,386 & 982 & 5,782 & 10,655 & 1,294 & 7,821 & 1,350 & 2,759 & 6,197 & 2,758 & 2,608 & 693 & $66,755.00$ \\
\hline Construction & 1,292 & 226 & 1,622 & 360 & 6,504 & 38,557 & 3,504 & 9,103 & 14,646 & 2,290 & 18,810 & 2,160 & 6,541 & 16,804 & 5,279 & 6,058 & 1,686 & $135,442.00$ \\
\hline $\begin{array}{l}\text { Wholesale and } \\
\text { Retail Trade }\end{array}$ & 509 & 94 & 512 & 131 & 2,213 & 7,280 & 772 & 5,428 & 2,827 & 404 & 2,560 & 406 & 779 & 1,808 & 863 & 843 & 281 & $27,710.00$ \\
\hline $\begin{array}{l}\text { Restaurants and } \\
\text { Hotels }\end{array}$ & 491 & & 388 & & 1,727 & 6,311 & 629 & 5,413 & 3,349 & 340 & 2,889 & 473 & 886 & 2,436 & 847 & 1,564 & 322 & $28,065.00$ \\
\hline $\begin{array}{l}\text { Transport, } \\
\text { Storage, and } \\
\text { Communication }\end{array}$ & 1,564 & 455 & 2,542 & 1,189 & 9,200 & 16,852 & 2,329 & 17,655 & 38,102 & 831 & 17,244 & 1,397 & 2,360 & 4,986 & 5,066 & 2,946 & 1,044 & $125,762.00$ \\
\hline $\begin{array}{l}\text { Finance, } \\
\text { Insurance, and } \\
\text { Real Estate } \\
\end{array}$ & 731 & 138 & 976 & 229 & 3,478 & 12,574 & 2,079 & 10,155 & 8,624 & 1,151 & 7,323 & 8,178 & 11,519 & 3,704 & 2,450 & 1,716 & 938 & $75,963.00$ \\
\hline $\begin{array}{l}\text { Renting and } \\
\text { Business } \\
\text { Services, } \\
\text { Ownership of } \\
\text { Dwellings } \\
\text { (Imputed Rent) }\end{array}$ & 574 & 212 & 470 & 121 & 3,052 & 14,687 & 1,472 & 8,562 & 21,207 & 672 & 5,359 & 1,175 & 3,001 & 8,636 & 3,747 & 4,259 & 1,720 & $78,926.00$ \\
\hline $\begin{array}{l}\text { Public } \\
\text { Administration } \\
\text { and Defence, } \\
\text { Compulsory } \\
\text { Social Security }\end{array}$ & 283 & 51 & 377 & 71 & 1,544 & 3,844 & 485 & 2,745 & 1,495 & 206 & 1,411 & 246 & 444 & 1,024 & 483 & 502 & 188 & $15,399.00$ \\
\hline
\end{tabular}




\section{Macrothink $\Lambda$ Institute ${ }^{m}$}

\begin{tabular}{|c|c|c|c|c|c|c|c|c|c|c|c|c|c|c|c|c|c|c|}
\hline Education & 260 & 53 & 258 & 60 & 1,154 & 2,605 & 385 & & 741 & 189 & 1,299 & 203 & 385 & 896 & 397 & 420 & 142 & $9,447.00$ \\
\hline $\begin{array}{l}\text { Health and } \\
\text { Social Work }\end{array}$ & 177 & 38 & 181 & 47 & 928 & 1,586 & 305 & 2,145 & 981 & 149 & 941 & 162 & 325 & 741 & 302 & 312 & 115 & $9,435.00$ \\
\hline $\begin{array}{l}\text { Other } \\
\text { Community, } \\
\text { Social, and } \\
\text { Personal } \\
\text { Service } \\
\text { Activities } \\
\end{array}$ & 261 & 66 & 278 & 67 & 1,288 & 4,367 & 332 & 2,476 & 1,923 & 182 & 1,247 & 210 & 629 & 1,745 & 421 & 393 & 189 & $16,074.00$ \\
\hline Total Input & $\begin{array}{l}26,121 . \\
00\end{array}$ & $\begin{array}{l}4,769 . \\
00\end{array}$ & $\begin{array}{l}25,495 . \\
00\end{array}$ & $\begin{array}{l}5,926 . \\
00\end{array}$ & $\begin{array}{l}116,992 . \\
00\end{array}$ & $\begin{array}{l}363,796 . \\
00\end{array}$ & $\begin{array}{l}40,810 . \\
00\end{array}$ & $\begin{array}{l}253,448 . \\
00\end{array}$ & $\begin{array}{l}134,782 . \\
00\end{array}$ & $\begin{array}{l}18,845 . \\
00\end{array}$ & $\begin{array}{l}134,552 . \\
00\end{array}$ & $\begin{array}{l}20,137 . \\
00\end{array}$ & $\begin{array}{l}45,748 . \\
00\end{array}$ & $\begin{array}{l}85,000 . \\
00\end{array}$ & $\begin{array}{l}38,248 . \\
00\end{array}$ & $\begin{array}{l}39,310 . \\
00\end{array}$ & $\begin{array}{l}13,498 . \\
00\end{array}$ & $1,367,477.00$ \\
\hline
\end{tabular}

Note. Obtained from the General Authority for Statistics, in addition to author's calculation

Appendix B. Final Use (SAR Millions)

\begin{tabular}{|c|c|c|c|c|c|c|c|c|c|c|c|c|}
\hline Init; & Sectors & $\begin{array}{l}\text { Final } \\
\text { consumption } \\
\text { expenditure by } \\
\text { households } \\
\text { (FUSE1) }\end{array}$ & $\begin{array}{l}\text { Final } \\
\text { consumption } \\
\text { expenditure by } \\
\text { government } \\
\text { (FUSE2) }\end{array}$ & $\begin{array}{l}\text { Total Final } \\
\text { consumption } \\
\text { expenditure } \\
\text { (FUSE3) }\end{array}$ & $\begin{array}{l}\text { Gross fixed } \\
\text { capital } \\
\text { formation } \\
\text { (FUSE4) }\end{array}$ & $\begin{array}{l}\text { Changes in } \\
\text { inventories } \\
\text { (FUSE5) }\end{array}$ & $\begin{array}{l}\text { Gross fixed } \\
\text { capital formation } \\
+ \text { Change in } \\
\text { inventories }\end{array}$ & $\begin{array}{l}\text { Exports of } \\
\text { oil }\end{array}$ & $\begin{array}{l}\text { Exports of } \\
\text { non-oil } \\
\text { goods }\end{array}$ & $\begin{array}{l}\text { Exports of } \\
\text { services }\end{array}$ & $\begin{array}{l}\text { EXPORTS } \\
\text { (TOTAL) }\end{array}$ & $\begin{array}{l}\text { FINAL } \\
\text { USES }\end{array}$ \\
\hline $\mathrm{ACT}(1)$ & Agriculture, Forests & $33,419.00$ & $1,872.00$ & $35,291.00$ & & $29,516.00$ & $29,516.00$ & & $2,257.00$ & & $2,257.00$ & $67,064.00$ \\
\hline $\mathrm{ACT}(2)$ & Fishing & $7,588.00$ & & $7,588.00$ & & 116.00 & 116.00 & & 40.00 & & 40.00 & $7,744.00$ \\
\hline $\operatorname{ACT}(3)$ & $\begin{array}{l}\text { Crude Petroleum and } \\
\text { Natural Gas Extraction }\end{array}$ & & 205.00 & 205.00 & & $1,340.00$ & $1,340.00$ & $513,181.00$ & & & $513,181.00$ & $514,726.00$ \\
\hline $\mathrm{ACT}(4)$ & Other Mining & 47.00 & 108.00 & 155.00 & & 362.00 & 362.00 & & $1,382.00$ & & $1,382.00$ & $1,899.00$ \\
\hline $\mathrm{ACT}(5)$ & Petroleum Refining & $23,357.00$ & & $23,357.00$ & & $2,108.00$ & $2,108.00$ & $125,463.00$ & & & $125,463.00$ & $150,928.00$ \\
\hline $\mathrm{ACT}(6)$ & Other Manufacturing & $395,191.00$ & $1,282.00$ & $396,473.00$ & $356,585.00$ & $84,593.00$ & $441,178.00$ & & $189,659.00$ & & $189,659.00$ & $1,027,310.00$ \\
\hline $\mathrm{ACT}(7)$ & Electricity, Gas, and Water & $39,880.00$ & $10,072.00$ & $49,952.00$ & & 305.00 & 305.00 & & & 4.00 & 4.00 & $50,261.00$ \\
\hline $\mathrm{ACT}(8)$ & Construction & $10,211.00$ & & $10,211.00$ & $270,346.00$ & - & $270,346.00$ & & & 634.00 & 634.00 & $281,191.00$ \\
\hline $\mathrm{ACT}(9)$ & Wholesale and Retail Trade & $19,185.00$ & & $19,185.00$ & & - & - & & & 80.00 & 80.00 & $19,265.00$ \\
\hline
\end{tabular}




\section{Macrothink}

Business and Economic Research ISSN 2162-4860

\begin{tabular}{|c|c|c|c|c|c|c|c|c|c|}
\hline $\mathrm{ACT}(10)$ & Restaurants and Hotels & $63,895.00$ & & $63,895.00$ & 1.00 & 1.00 & 841.00 & 841.00 & $64,737.00$ \\
\hline $\operatorname{ACT}(11)$ & $\begin{array}{l}\text { Transport, Storage, and } \\
\text { Communication }\end{array}$ & $81,378.00$ & $8,849.00$ & $90,227.00$ & - & - & $17,236.00$ & $17,236.00$ & $107,463.00$ \\
\hline $\mathrm{ACT}(12)$ & $\begin{array}{l}\text { Finance, Insurance, and } \\
\text { Real Estate }\end{array}$ & $47,475.00$ & $1,335.00$ & $48,810.00$ & - & - & $3,202.00$ & $3,202.00$ & $52,012.00$ \\
\hline $\mathrm{ACT}(13)$ & $\begin{array}{l}\text { Renting and Business } \\
\text { Services, Ownership of } \\
\text { Dwellings (Imputed Rent) }\end{array}$ & $199,694.00$ & $2,182.00$ & $201,876.00$ & $(1.00)$ & $(1.00)$ & 584.00 & 584.00 & $202,459.00$ \\
\hline АCT(14) & $\begin{array}{l}\text { Public Administration and } \\
\text { Defense, Compulsory social } \\
\text { security }\end{array}$ & $18,438.00$ & $300,199.00$ & $318,637.00$ & 1.00 & 1.00 & & - & $318,638.00$ \\
\hline $\mathrm{ACT}(15)$ & Education & $33,482.00$ & $191,341.00$ & $224,823.00$ & - & - & & - & $224,823.00$ \\
\hline $\mathrm{ACT}(16)$ & Health and Social Work & $33,341.00$ & $82,402.00$ & $115,743.00$ & - & - & & - & $115,743.00$ \\
\hline $\mathrm{ACT}(17)$ & $\begin{array}{l}\text { Other Community, Social, } \\
\text { and Personal Service } \\
\text { Activities }\end{array}$ & $16,384.00$ & $31,134.00$ & $47,518.00$ & 1.00 & 1.00 & 203.00 & 203.00 & $47,722.00$ \\
\hline
\end{tabular}

Note. Obtained from the General Authority for Statistics. In addition to author's calculation. 
Appendix C. Value Added (SAR Millions)

\begin{tabular}{|c|c|c|c|c|c|c|c|c|c|c|c|c|c|c|c|c|c|c|}
\hline Val & Type & $\operatorname{ACT}(1)$ & $\begin{array}{l}\mathrm{ACT}(2 \\
)\end{array}$ & $\mathrm{ACT}(3)$ & $\operatorname{ACT}(4)$ & $\mathrm{ACT}(5)$ & ACT(6) & $\operatorname{ACT}(7)$ & $\mathrm{ACT}(8)$ & $\operatorname{ACT}(9)$ & $\begin{array}{l}\mathrm{ACT}(10 \\
)\end{array}$ & $\operatorname{ACT}(11)$ & $\begin{array}{l}\mathrm{ACT}(12 \\
)\end{array}$ & $\operatorname{ACT}(13)$ & $\operatorname{ACT}(14)$ & $\mathrm{ACT}(15)$ & $\begin{array}{l}\mathrm{ACT}(16 \\
)\end{array}$ & $\begin{array}{l}\mathrm{ACT}(17 \\
)\end{array}$ \\
\hline $\operatorname{Val}(1)$ & $\begin{array}{l}\text { Compensati } \\
\text { on of } \\
\text { Employmen } \\
t\end{array}$ & $8,651.00$ & 364.00 & $\begin{array}{l}30,469.0 \\
0\end{array}$ & $\begin{array}{l}1,284.0 \\
0\end{array}$ & $\begin{array}{l}7,189.0 \\
0\end{array}$ & $48,250.00$ & $\begin{array}{l}12,382 . \\
00\end{array}$ & $\begin{array}{l}39,244.0 \\
0\end{array}$ & $\begin{array}{l}48,326.0 \\
0\end{array}$ & $\begin{array}{l}14,543.0 \\
0\end{array}$ & $\begin{array}{l}33,465.0 \\
0\end{array}$ & $\begin{array}{l}15,266 . \\
00\end{array}$ & $\begin{array}{l}20,649.0 \\
0\end{array}$ & $\begin{array}{l}195,314 . \\
00\end{array}$ & $\begin{array}{l}157,051 . \\
00\end{array}$ & $\begin{array}{l}42,794 . \\
00\end{array}$ & $\begin{array}{l}16,241 . \\
00\end{array}$ \\
\hline $\operatorname{Val}(2)$ & $\begin{array}{l}\text { Other Taxes } \\
\text { Less } \\
\text { Subsidies } \\
\text { on } \\
\text { Production } \\
\end{array}$ & $\begin{array}{l}(3,245.0 \\
0)\end{array}$ & $\begin{array}{l}(164.0 \\
0)\end{array}$ & & 194.00 & & $(2,520.00)$ & 277.00 & $3,152.00$ & $8,197.00$ & $1,150.00$ & $3,010.00$ & 758.00 & $1,742.00$ & & 526.00 & $\begin{array}{l}1,216.0 \\
0\end{array}$ & 958.00 \\
\hline $\operatorname{Val}(3)$ & $\begin{array}{l}\text { Operating } \\
\text { Surplus }\end{array}$ & $\begin{array}{l}56,502.0 \\
0\end{array}$ & $\begin{array}{l}2,981.0 \\
0\end{array}$ & $\begin{array}{l}613,324 . \\
00\end{array}$ & $\begin{array}{l}10,245 . \\
00\end{array}$ & $\begin{array}{l}75,781 . \\
00\end{array}$ & $\begin{array}{l}201,552.0 \\
0\end{array}$ & $\begin{array}{l}35,760 . \\
00\end{array}$ & $\begin{array}{l}110,732 . \\
00\end{array}$ & $\begin{array}{l}180,061 . \\
00\end{array}$ & $\begin{array}{l}17,551.0 \\
0\end{array}$ & $\begin{array}{l}140,133 . \\
00\end{array}$ & $\begin{array}{l}82,391 . \\
00\end{array}$ & $\begin{array}{l}203,660 . \\
00\end{array}$ & $\begin{array}{l}24,759.0 \\
0\end{array}$ & $\begin{array}{l}14,737.0 \\
0\end{array}$ & $\begin{array}{l}34,739 . \\
00\end{array}$ & $\begin{array}{l}27,111.0 \\
0\end{array}$ \\
\hline $\begin{array}{l}\text { IMP( } \\
1)\end{array}$ & $\begin{array}{l}\text { Imports } \\
\text { (GOODS) } \\
\text { (cif) }\end{array}$ & $\begin{array}{l}27,665.0 \\
0\end{array}$ & 329.00 & & $\begin{array}{l}5,275.0 \\
0\end{array}$ & $\begin{array}{l}11,037 . \\
00\end{array}$ & $\begin{array}{l}460,404.0 \\
0\end{array}$ & & & & & & & & & & & \\
\hline $\begin{array}{l}\text { IMP( } \\
\text { 2) }\end{array}$ & $\begin{array}{l}\text { Imports } \\
\text { (SERVICE } \\
\text { S) }\end{array}$ & & & & & & & & $\begin{array}{l}10,056.0 \\
0\end{array}$ & $\begin{array}{l}16,356.0 \\
0\end{array}$ & $\begin{array}{l}40,714.0 \\
0\end{array}$ & $\begin{array}{l}35,279.0 \\
0\end{array}$ & $\begin{array}{l}9,422.0 \\
0\end{array}$ & $9,586.00$ & $\begin{array}{l}28,964.0 \\
0\end{array}$ & $\begin{array}{l}23,708.0 \\
0\end{array}$ & $\begin{array}{l}7,069.0 \\
0\end{array}$ & $\begin{array}{l}5,987.0 \\
0\end{array}$ \\
\hline $\begin{array}{l}\text { IMP( } \\
\text { 3) }\end{array}$ & $\begin{array}{l}\text { Imports } \\
\text { (cif) }\end{array}$ & $\begin{array}{l}27,665.0 \\
0 \\
\end{array}$ & 329.00 & - & $\begin{array}{l}5,275.0 \\
0 \\
\end{array}$ & $\begin{array}{l}11,037 . \\
00\end{array}$ & $\begin{array}{l}460,404.0 \\
0 \\
\end{array}$ & - & $\begin{array}{l}10,056.0 \\
0 \\
\end{array}$ & $\begin{array}{l}16,356.0 \\
0 \\
\end{array}$ & $\begin{array}{l}40,714.0 \\
0 \\
\end{array}$ & $\begin{array}{l}35,279.0 \\
0 \\
\end{array}$ & $\begin{array}{l}9,422.0 \\
0 \\
\end{array}$ & $9,586.00$ & $\begin{array}{l}28,964.0 \\
0 \\
\end{array}$ & $\begin{array}{l}23,708.0 \\
0 \\
\end{array}$ & $\begin{array}{l}7,069.0 \\
0 \\
\end{array}$ & $\begin{array}{l}5,987.0 \\
0 \\
\end{array}$ \\
\hline $\begin{array}{l}\text { Total } \\
\text { Value } \\
\text { Adde } \\
\text { d } \\
\end{array}$ & $\begin{array}{l}\text { Value } \\
\text { Added Total }\end{array}$ & $\begin{array}{l}34,243.0 \\
0\end{array}$ & $\begin{array}{l}2,852.0 \\
0\end{array}$ & $\begin{array}{l}643,793 . \\
00\end{array}$ & $\begin{array}{l}6,448.0 \\
0\end{array}$ & $\begin{array}{l}71,933 . \\
00\end{array}$ & $\begin{array}{l}(213,122.0 \\
0)\end{array}$ & $\begin{array}{l}48,419 . \\
00\end{array}$ & $\begin{array}{l}143,072 . \\
00\end{array}$ & $\begin{array}{l}220,228 . \\
00\end{array}$ & $\begin{array}{l}(7,470.0 \\
0)\end{array}$ & $\begin{array}{l}141,329 . \\
00\end{array}$ & $\begin{array}{l}88,993 . \\
00\end{array}$ & $\begin{array}{l}216,465 . \\
00\end{array}$ & $\begin{array}{l}191,109 . \\
00\end{array}$ & $\begin{array}{l}148,606 . \\
00\end{array}$ & $\begin{array}{l}71,680 . \\
00\end{array}$ & $\begin{array}{l}38,323 . \\
00\end{array}$ \\
\hline
\end{tabular}

Note. Obtained from the General Authority for Statistics, in addition to author's calculation.

\section{Copyright Disclaimer}

Copyright for this article is retained by the author(s), with first publication rights granted to the journal.

This is an open-access article distributed under the terms and conditions of the Creative Commons Attribution license (http://creativecommons.org/licenses/by/4.0/). 